\title{
FLESH YIELD OF SMALL INDIGENOUS FISHES FROM THE RIVER PADMA, RAJSHAHI, BANGLADESH
}

\author{
Sarmin Akther \\ Department of Zoology, Rajshahi University, Rajshahi- 6205, Bangladesh
}

The small indigenous fishes (SIS) of Bangladesh are generally considered to those which grow to a length of approximately $5-25 \mathrm{~cm}$ or 9 inches at maturity (Felts et at. 1996). Small fishes are generally eaten with bones, whereas in large fish most or all bones are discarded as plate waste. In humans, the fractional calcium absorption is found to be $24 \pm 6 \%$ from small fishes and $22 \pm 6 \%$ from milk (Larsen et al. 2000). The small fishes are captured with simple gears and even children can capture with their hands from water bodies (Alikunhi et al. 1972, Hossain and Afroze 1991, Hossain 1994, Felts et al. 1996).

Considerable number of works have been done on flesh contents of of fishes by different workers such as Mookherjee and Basu (1946), CSIR (1962), Hossain and Afroze (1991), Hossain et al. (1999), Islam and Joadder (2005), and Flowra and Bhuiyan (2013). Sultana (2012) reported that percentage of edible flesh is higher in small sized fishes compared to large sized fishes. The present attempt was made to asses edible portion of small fish product after dressing.

The study was carried out during the period from July 2008 - June 2011. Samples of Glossogobius giuris, Colisa fasciata, Puntius ticto, Eutropiichthyes vacha, Corica soborna and some mixed fishes (Chanda nama, C. ranga, Amblypharyngodon mola, Mastacembelus pancalus, Xenentodon cancila) were collected randomly from different fish markets and local landing centre of Rajshahi city.

The fishes were washed with clean water and the excess water was soaked with kitchen tissue. First, the whole body weight of the samples were recorded. Then the fishes were cut off and the scales were scrapped off. Viscera was removed and the fish was weighted again. Weight of all the wastes (viscera, fins, scales etc.) were taken. The percentage of the flesh after dressing were calculated and the ratios of the edible parts were determined from the following formula-

$$
\text { Percentgae of edible portion }=\frac{\text { Total weight of a fish }(\mathrm{g})-\text { Total weight of waste }(\mathrm{g})}{\text { Total weight of a fish }(\mathrm{g})} \times 100
$$

The range and mean \pm SD total length (TL) and total weight (TW), the weight after dressing (WAD) was measured from the group weight. G. giuris having the maximum mean TL $106.4 \pm 18.29 \mathrm{~mm}$, the ratio between the edible and non edible portion was found as $1: 0.204$ (Table 1).

E-mail: sarminhamim@gmail.com 
Table 1. Total length (TL), weight(TW), weight after dressing (WAD) of five species of small indigenous fishes

\begin{tabular}{|c|c|c|c|c|c|c|c|c|c|c|c|c|}
\hline \multirow[t]{2}{*}{ Species } & \multicolumn{3}{|c|}{ Range of TL (mm) } & \multicolumn{3}{|c|}{ Range of TW (g) } & \multicolumn{3}{|c|}{ Range of WAD (g) } & \multicolumn{3}{|c|}{ Per kg weight of fish } \\
\hline & Min & $\operatorname{Max}$ & $\begin{array}{l}\text { Mean } \\
\pm \mathrm{SD}\end{array}$ & Min & $\operatorname{Max}$ & $\begin{array}{l}\text { Mean } \\
\pm \mathrm{SD}\end{array}$ & Min & $\operatorname{Max}$ & $\begin{array}{l}\text { Mean } \\
\pm \mathrm{SD}\end{array}$ & $\begin{array}{c}\text { Weight after } \\
\text { dressing } \\
\text { washing (g) }\end{array}$ & $\begin{array}{l}\text { Weight of } \\
\text { waste } \\
\text { products (g) }\end{array}$ & \\
\hline $\begin{array}{l}\text { Glossogobiusgiur } \\
\text { is }\end{array}$ & 89 & 140 & $\begin{array}{c}106.4 \\
\pm 18.29\end{array}$ & 2.9 & 25.2 & $\begin{array}{l}12.33 \\
\pm 3.99\end{array}$ & 81.1 & 84.5 & $\begin{array}{l}82.99 \\
\pm 1.25\end{array}$ & 829.90 & 170.10 & $1: 0.204$ \\
\hline Colisa fasciata & 44 & 90 & $\begin{aligned} & 75.8 \\
\pm & 10.10\end{aligned}$ & 5.8 & 10.8 & $\begin{array}{c}8.16 \\
\pm 1.88\end{array}$ & 79.1 & 88.4 & $\begin{array}{l}84.15 \\
\pm 4.14\end{array}$ & 841.50 & 158.50 & $1: 0.188$ \\
\hline Puntius ticto & 41 & 102 & $\begin{array}{r}67.9 \\
\pm 16.40\end{array}$ & 1.2 & 10.9 & $\begin{array}{c}5.37 \\
\pm 3.10\end{array}$ & 64.6 & 79.0 & $\begin{array}{l}72.49 \\
\pm 5.24\end{array}$ & 724.90 & 275.90 & $1: 0.380$ \\
\hline $\begin{array}{l}\text { Euthropiicht } \\
\text { yes vacha }\end{array}$ & 45 & 80 & $\begin{array}{r}62.95 \\
\pm 13.47\end{array}$ & 0.8 & 2.3 & $\begin{array}{c}1.20 \\
\pm 0.28\end{array}$ & 43.3 & 46.0 & $\begin{array}{l}44.93 \\
\pm 0.73\end{array}$ & 898.60 & 101.40 & $1: 0.112$ \\
\hline Corica soborna & 12 & 27 & $\begin{array}{l}17.85 \\
\pm 5.58\end{array}$ & 0.41 & 1.63 & $\begin{array}{c}1.03 \\
\pm 0.64\end{array}$ & 47.91 & 49.76 & $\begin{array}{l}48.77 \\
\pm 0.61\end{array}$ & 975.40 & 24.60 & $1: 0.025$ \\
\hline Mixed fishes & 19 & 205 & $\begin{array}{c}64.6 \\
\pm 49.43\end{array}$ & 0.20 & 16.28 & $\begin{array}{c}3.53 \\
\pm 4.70\end{array}$ & 67.8 & 83.5 & $\begin{array}{l}72.34 \\
\pm 5.08\end{array}$ & 723.40 & 276.60 & $1: 0.382$ \\
\hline
\end{tabular}


C. fasciata having the maximum mean TL $75.8 \pm 10.10 \mathrm{~mm}$, the ratio between the edible and non edible portion was found as 1:0.188 whereas, P. ticto same sized fish mean $\mathrm{TL}=67.9 \pm 16.40 \mathrm{~mm}$ have the mentioned ratio as 1:0.380 (Table 1) After dressing the percentage of edible flesh portion was 84.15 for C. fasciata and 72.49 for P. ticto. E. vacha (mean TL $=62.95 \pm 13.47 \mathrm{~mm}$ ) is a smaller fish, the ratio between the edible and non edible portion were 1:0.112 and percentage of edible portion was $89.86 \%$. C. soborna (mean TL $=17.85 \pm 5.58 \mathrm{~mm}$ ) is a smaller clupeid fish. The ratio between edible and non edible portion were 1:0.025 and after dressing and washing percentage of edible flesh portion was 97.54\% for C. soborna.

Very little information related to this research work are found. Hossain et al. (1999), Sultana (2012), Flowra and Bhuiyan (2013) reported more or less same result in this SIS fishes.

Acknowledgement: The author is very much grateful to Prof. Dr. N.I.M. Abdus Salam Bhuiyan, Department of Zoology, University of Rajshahi, Rajshahi, who her supervisor for invaluable guidance, suggestion and critical comments on the results. This study was funded by the NSICT fellowship provided by Ministry of Science and Technology.

\section{LITERATURE CITED}

ALIKUNHI KH, SUKUMARAN KK AND PARMESWARAN S. 1972.Studies on composite fish culture: Production by compatible combinations of Indian and Chinese carps. $J$. Ind. Fish. Asso.1: 26-27.

CSIR. 1962. Fishes and fisheries raw materials, India, vol. IV, P. 132.

FLOWRA F.A. AND BHUIYAN A.S. 2013.Quality of edible portion of dressed and powdered small fish and prawns. Univ. j. zool. Rajshahi. Univ. 32:34-42.

FELTS RA, RAJTS F AND AKHTERUZZAMAN M. 1996. Small Indigenous fish species culture in Bangladesh. IFADEP Sub-Project-2.Development of Inland Fisheries. 41p.

HOSSAIN MA AND AFROZE S. 1991.Small fisheries as resource in rural Bangladesh. Fishbyte. 9(2): 15-18.

HOSSAIN MA, PARWEEN S AND MORTAZA MG. 1999.Estimation of edible contents of some freshwater fish species.Univ. j. zool. Rajshahi Univ., 18: 169-171.

HOSSAIN MM. 1994. Exportable dried fishery products of Bangladesh. Bangladesh J. Fish. Res. 1: 83-90.

ISLAM MN AND JOADDER AR. 2005. Seasonal variation of the proximate composition of freshwater gobi, Glossobgobiusgiuris (Hamilton) from the River Padma. Pakistan Journal of Biological Sciences. 8(4): 532-536.

LARSEN T. THILSTED SH, KONGSBAK K AND HANSEN M. 2000.Whole small fish as a rich calcium source. Br. J. Nutr. 83: 191-196.

MAZID MA. 2005. Manual in culture of small and threatened indigenous fish species. Bangladesh Fisheries Research Institute, Department of Fisheries, Bangladesh Agricultural University and Ministry of Fisheries and Livestock. 88 p. 
MOOKHERJEE HK AND BASU SP. 1946.Life history of Amblypharyngodonmola (Ham) a delicate food fish of Bengal.Sci. \& Cult., Calcutta. 12(1): 54-56.

ROSS N, THILSTED SH AND ISLAM MM. 2006. Small indigenous fish species in aquaculture in Bangladesh.contribution to vitamin A, calcium and iron intakes. Int. J. Food, Sci. Nutr. 53: 425-737.

SULTANA, S. 2012. Flesh estimation of some SIS fish. J. Life Earth Sci. 7: 105-108.

Manuscript on 08 April 2015 and Revised on 30 June 2015 